\title{
The Consideration of the Caddo Area in "Food Production in Native North America: An Archaeological Perspective"
}

Timothy K. Perttula

Follow this and additional works at: https://scholarworks.sfasu.edu/ita

Part of the American Material Culture Commons, Archaeological Anthropology Commons, Environmental Studies Commons, Other American Studies Commons, Other Arts and Humanities Commons, Other History of Art, Architecture, and Archaeology Commons, and the United States History Commons

Tell us how this article helped you.

This Article is brought to you for free and open access by the Center for Regional Heritage Research at SFA ScholarWorks. It has been accepted for inclusion in Index of Texas Archaeology: Open Access Gray Literature from the Lone Star State by an authorized editor of SFA ScholarWorks. For more information, please contact cdsscholarworks@sfasu.edu. 


\section{The Consideration of the Caddo Area in "Food Production in Native North America: An Archaeological Perspective"}

\section{Creative Commons License}

\section{(c) (1) \&}

This work is licensed under a Creative Commons Attribution-NonCommercial 4.0 International License 


\title{
The Consideration of the Caddo Area in "Food Production in Native North America: An Archaeological Perspective"
}

\author{
Timothy K. Perttula
}

Kristen J. Gremillion (2018:ix) has written "a highly selective survey of Native North American food production systems from an archaeological perspective," with a particular focus on plant food production in the Eastern Woodlands and the Southwest. The time frame of the book spans the period from ca. 3000 B.C. to post-European contact, extending up to ca. A.D. 1800. The archaeological evidence for plant food production in the Caddo Archaeological Area of Southwest Arkansas, Northwest Louisiana, eastern Oklahoma, and East Texas is mentioned by Gremillion (2018:72), but only rather briefly in her chapter entitled "the Rise of the Three Sisters: Maize in the Eastern Woodlands."

First, it should be mentioned that her map of the Eastern Woodlands that depicts the locations of sites and archaeological region does not accurately illustrate the extent of the Caddo Area (Gremillion 2018:Figure 4.1). Gremillion's map extends the Caddo Area all the way to the Gulf of Mexico and well west into what would be prairie natural regions in North Central and Central Texas. Second, her discussion of food production in the Caddo Area is only a single paragraph, and relies on the results of stable isotope analyses of ancestral Caddo peoples (i.e., Rogers 2011; Wilson and Perttula 2013; Perttula et al. 2014) rather than a consideration of the macrobotanical remains recovered from flotation samples at ancestral Caddo sites. Even so, Gremillion (2018:72) concludes that in the Caddo area:

on the western edge of the Eastern Woodlands, maize agriculture was gradually incorporated into mixed economies that continued to make substantial use of hunted and gathered foods as well as EAS [Eastern Agricultural Complex] crops.

What is currently known concerning food production by ancestral Caddo peoples has been bolstered in recent years by several studies of recovered macrobotanical remains from excavated Woodland period and later Caddo settlements and mound centers (see Bush 2008, 2009, 2012, 2014a, 2014b, 2015; Bush et al. 2014; Dering and Perttula 2011; Trubitt et al. 2016), as well as the radiocarbon dating of maize samples from sites in the southern Caddo area (Perttula et al. 2014:Table 1). These studies indicate that while maize may have been grown and used by Woodland period groups prior to A.D. 800, the sustained consumption and importance of maize in the southern Caddo area was not until after ca. A.D. 1200/1300, and maize (of two kinds, a spring or little corn and summer or flower corn) continued in importance after ca. A.D. 1680, during the Historic Caddo period. The ubiquity of maize in flotation samples from selected samples top 40-50 percent only after ca. A.D. 1200 (in the Middle Caddo period), and especially after ca. A.D. 1400, during the Late Caddo period.

The Caddo peoples had other cultigens or domesticated plants, including beans, squash (beginning in use in the Woodland period, see Bush 2008, 2009; Trubitt et al. 2016), and bottle gourd. Charred beans from a burned structure at the Eli Moores site (41BW2) on the Red River have been directly dated to A.D. 1487-1651 (Perttula and Selden 2014:Table 16). Starchy and oily seeds from probable cultivated plants such as chenopod, knotweed, amaranth, maygrass, little barley, panic grass, sumpweed, and sunflower are also commonly represented in ancestral Caddo macrobotanical remains, but not to the level seen in other parts of the Eastern Woodlands. Such Eastern Agricultural Complex plants were 
important parts of the food production economy elsewhere in the Eastern Woodlands after ca. A.D. 1000 (Gremillion 2018:73-74), and perhaps they became better represented around and after ca. A.D. 1200 in ancestral Caddo sites, although they also were likely used as wild plant foods in sites in the Red and Ouachita River basins dating to Woodland period times (Bush 2009; Trubitt et al. 2016).

Lastly, the macrobotanical remains from some ancestral Caddo sites have persimmon seeds (see Bush 2014a, 2014b, 2015; Fields et al. 2014). Bush (2014b:69) suggests that persimmon trees were cultivated in "orchards" by Caddo peoples.

\section{References Cited}

Bush, L. L.

2008 Macrobotanical Remains from the 2005 and 2006 Texas Archeological Society Field Schools at the Gene and Ruth Ann Stallings Site (41LR297). In Archaeological Investigations at the Gene and Ruth Ann Stallings Ranch, Lamar County, Texas, edited by S. A. Skinner. Draft MS on file with the editor and the Texas Archeological Society.

2009 The Development of Plant Cultivation in Northeast Texas. Paper presented at the 2009 Society for American Archaeology Conference.

2012 Macrobotanical Analysis. In Archeology of the Nadaco Caddo: The View from the Pine Tree Mound Site (41HS15), Harrison County, Texas, edited by R. C. Fields and E. F. Gadus, pp. 727-772. 2 Vols., Reports of Investigations No. 164. Prewitt \& Associates, Inc., Austin.

2014a Macrobotanical Plant Remains. In Testing and Data Recovery Excavations at 11 Native American Archeological Sites along the U.S. Highway 271 Mount Pleasant Relief Route, Titus County, Texas, by R. C. Fields, V. L. Hatfield, D. Burden, E. F. Gadus, M. C. Wilder, and K. W. Kibler, Appendix F. 2 Vols., Reports of Investigations No. 168. Prewitt \& Associates, Inc., Austin.

2014b Eli Moores Site (41BW2) Plant Remains. In The Eli Moores Site, a $17^{\text {th }}$ to early $18^{\text {th }}$ Century Caddo Site on the Red River, Bowie County, Texas, edited by T. K. Perttula, pp. 63-73. Special Publication No. 31. Friends of Northeast Texas Archaeology, Austin and Pittsburg.

2015 Plant Remains from Site 41PN175, Panola County, Texas. In Data Recovery Investigations: Murvaul Creek Site (41PN175), Panola County, Texas (CSJ 1222-01-014, Atlanta District), by A. McKee, C. D. Frederick, T. K. Perttula, R. Z. Selden et al., pp. 269-286. Report No. 165, Archeological Studies Program, Environmental Affairs Division, Texas Department of Transportation, Austin.

Bush, L. L., L. Schniebs, and T. K. Perttula

2014 Floral and Faunal Remains from the Kitchen Branch Site, and the Results of Organic Residue Analysis of Ceramic Sherds. In Archeological Investigations at the Kitchen Branch (41CP220), B. J. Horton (41CP20), and Keering (41CP21) Sites, Big Cypress Creek Basin, Camp County, Texas, edited by T. K. Perttula and M. D. Miller, pp. 461-487. AmaTerra Environmental, Inc., Austin.

Dering, P. and T. K. Perttula

2011 Plant Remains from the Lang Pasture Site (41AN38), Anderson County, Texas, and the Character of Caddo Agriculture in the Upper Neches River Basin. In Archeological Investigations at the Lang Pasture Site (41AN38) in the Upper Neches River Basin of East Texas, assembled and edited by T. K. Perttula, D. B. Kelley, and R. A. Ricklis, pp. 349-371. Report 129, Archeological Studies Program, Environmental Affairs Division, Texas Department of Transportation, Austin.

Gremillion, K. J.

2018 Food Production in Native North America: An Archaeological Perspective. The SAA Press, Washington, D.C.

Perttula, T. K. and R. Z. Selden, Jr.

2014 Radiocarbon Dating. In The Eli Moores Site, a 17 th to early $18^{\text {th }}$ Century Caddo Site on the Red River, Bowie County, Texas, edited by T. K. Perttula, pp. 74-75. Special Publication No. 31. Friends of Northeast Texas Archaeology, Austin and Pittsburg. 
Perttula, T. K., R. Z. Selden, Jr., and D. Wilson

2014 Corn is Life: Temporal Trends in the Use of Corn (Zea mays) by Caddo Peoples from Radiocarbondated Samples and Stable Isotope Analyses. Bulletin of the Texas Archeological Society 85:159-181.

Rogers, J. D.

2011 Stable Isotope Analysis and Diet in Eastern Oklahoma. Southeastern Archaeology 30:96-107.

Trubitt, M. B., L. L. Bush, L. S. Kelly, and K. Leslie

2016 Ouachita Mountains Foodways: Preliminary Results from 2013-2014 Excavations at 3MN298. Caddo Archeology Journal 26:50-79.

Wilson, D. and T. K. Perttula

2013 Reconstructing the Paleodiet of the Caddo through Stable Isotopes. American Antiquity 78(4):702-723. 